\title{
The Evaluation of Oxidative Stress Levels in Obesity
}

\author{
MIRELA ELENA EPINGEAC ${ }^{1}$, MIHNEA ALEXANDRU GAMAN²*, CAMELIA CRISTINA DIACONU², MOHAMED GAD², \\ AMELIA MARIA GAMAN ${ }^{1,4}$ \\ 'University of Medicine and Pharmacy of Craiova, Department of Pathophysiology, 2 Petru Rares Str., 200349, Craiova, Romania \\ ${ }^{2}$ Carol Davila University of Medicine and Pharmacy, 8 Eroii Sanitari Blvd., 050474, Bucharest, Romania \\ ${ }^{3}$ Department of Cardiovascular Medicine, Heart and Vascular Institute, Cleveland Clinic, 9500 Euclid Ave J2-606, Cleveland, $\mathrm{OH}$ \\ 44195, United States of America \\ ${ }^{4}$ Clinic of Hematology, Filantropia City Hospital, 1 Filantropiei Str., 20043, Craiova, Romania
}

\begin{abstract}
The association between elevated values of reactive oxygen species and a decreased antioxidant capacity defines oxidative stress. Oxidative stress involvement is blamed in many diseases, including obesity. We evaluated oxidative stress levels by FORT (Free Oxygen Radical Testing - reactive oxygen species levels) and FORD (Free Oxygen Radical Defence - antioxidant capacity value) assays in obese subjects vs. controls. FORT values were high and FORD values were low in obese patients vs. controls, notably in obese subjects with comorbidities (diabetes, hypertension, dyslipidaemia, coronary heart disease, anaemia, hepatic steatosis). We found positive correlations between FORT values and total cholesterol, uric acid, triglycerides, $L D L$, body mass index, HDL/total cholesterol ratio, and negative correlations between FORT and age, HDL. FORD levels correlated oppositely to FORT. Our results suggest that obesity and oxidative stress are linked.
\end{abstract}

Keywords: Oxidative Stress, Obesity, Reactive Oxygen Species, Antioxidants, Comorbidities

Obesity is a complex metabolic disorder characterized by an excessive accumulation of adipose tissue. There is a clear link between obesity and the development of metabolic syndrome, type 2 diabetes mellitus (T2DM), cardiovascular and liver disorders, possibly explained bya common putative element: oxidative stress [1-3].

The World Health Organization defines overweight as a body mass index (BMI) of 25.0 to $29.9 \mathrm{~kg} / \mathrm{m}^{2}$ and obesity as a BMI of $>30 \mathrm{~kg} / \mathrm{m}^{2}$ (first class obesity -BMI of 30.0 to $34.9 \mathrm{~kg} / \mathrm{m}^{2}$, second class obesity - BMI of 35.0 to $39.9 \mathrm{~kg} /$ $\mathrm{m}^{2}$ and third class obesity $-\mathrm{BMI}>40 \mathrm{~kg} / \mathrm{m}^{2}$ ). Recent studies have revealed that obesity-related risk factors depend not on the excess body weight, but rather on the regional distribution of the adipose tissue. Thus, abdominal fat accumulation stimulates inflammation and entertains a pro-oxidant state, becoming an important risk factor for obesity-related disorders [4]. Abdominal obesity is undoubtedly the most dangerous form of obesity. Several studies revealed a linear association between T2DM and $\mathrm{BMI}$, distribution of fat, and the relative proportions of lipids in insulin-sensitive tissues: liver, skeletal muscle and adipose tissue. Waist circumference has emerged as an excellent predictor of the risk to develop T2DM [6-9].

White adipose tissue secretes bioactive substances called adipokines: leptin, adiponectin, interleukin 6 (IL-6), tumour necrosis factor alpha (TNF- $\alpha$ ), plasminogen activator inhibitor type 1, adipsin, resistin, visfatin, apelin and others. In turn, adipokines generate reactive oxygen species (ROS) or reduce the antioxidant capacity, causing an increase in oxidative stress levels. An excessive amount of adipose tissue acts as a source of pro-inflammatory cytokines (TNF- $\alpha$, IL-1 or IL-6), explaining why obesity, via low-grade chronic inflammation, leads to an increase in ROS levels and induces oxidative stress. Other obesityrelated mechanisms that generate oxidative stress are: mitochondrial and peroxisomal oxidation of fatty acids, over-consumption of $\mathrm{O}_{2}$ in the mitochondrial respiratory chain, altered $\mathrm{O}_{2}$ metabolism caused by lipid-rich diets, decreased activity of antioxidant enzymes (superoxide dismutase, catalase and glutathione peroxidase), superoxide generation from NADPH oxidases, oxidative phosphorylation, auto-oxidation of glyceraldehydes, activation of protein kinase $C$ and polyol/hexosamine pathways. ROS are known to induce endothelial dysfunction, decrease vasodilator molecules (e.g. nitric oxide), increase endothelium-derived contractile factors, damage cell structures, favouring, thus, atherosclerosis, hypertension, heart failure, diabetes and hepatic steatosis $[3,9-11]$. Many studies have shown that oxidative stress also induces pancreatic â-cell dysfunction and insulin resistance, increasing the risk of T2DM in obese subjects [12-17].

Thus, we aimed to evaluate oxidative stress levels in obese patients with/without comorbidities vs. healthy controls.

\section{Experimental part}

We enrolled 20 healthy controls and 54 obese patients. Informed consent was obtained from all subjects prior to study inclusion. Patients were diagnosed with obesity based on BMI values. Hypertension, T2DM, dyslipidaemia, anaemia, coronary heart disease (CHD) and hepatic steatosis were assessed as comorbidities. Blood tests (complete blood count, lipid profile, uric acid etc) were run. OxS levels were evaluated using the Free Oxygen Radical Testing assay (FORT; normal range: $\leq 2.3 \mathrm{mmol} /$ $\mathrm{L}_{2} \mathrm{O}_{2}$ ). Antioxidant status was measured using the Free Oxygen Radical Defence (FORD; normal range: 1.07 -1.53 $\mathrm{mmol} / \mathrm{L}$ Trolox) test. The methods are described in detail elsewhere [18]. The study was approved by the Ethics Committee of the University of Medicine and Pharmacy of Craiova, Craiova, Romania (approval no. 40/27.03.2018). All procedures and experiments were carried out taking into consideration the ethical standards requested by the Helsinki Declaration of 1975, as revised in 2008(5), as well as the national law.

\section{Results and discussions}

The study group ( $62.63 \pm 8.57$ years, range $41-82$ years vs. $64.1 \pm 2.26$ years, range $61-69$ years in controls) included 44 women (81.48\%) and 10 men (18.52\%). 30 patients $(55.56 \%)$ resided in rural areas and 24 patients (44.44\%) in urban areas. Mean BMI was $37.01 \pm 3.77 \mathrm{~kg} /$

*email: mihneagaman@yahoo.com 
$\mathrm{m}^{2}$, range 31.83-47.93 (obesity class I: 18 patients, 33.30\% class II: 25 patients, $46.30 \%$; class III: 11 patients, $20.40 \%$ ) (fig. 1). We registered the following comorbidities: dyslipidaemia (53 patients, 98.15\%), hypertension ( 35 patients, 64.81\%), anaemia (24 patients, 44.44\%), T2DM (20 patients, 37.04\%), CHD (16 patients, $29.63 \%$ ) and hepatic steatosis (7 patients, 12.96\%) (fig. 2).

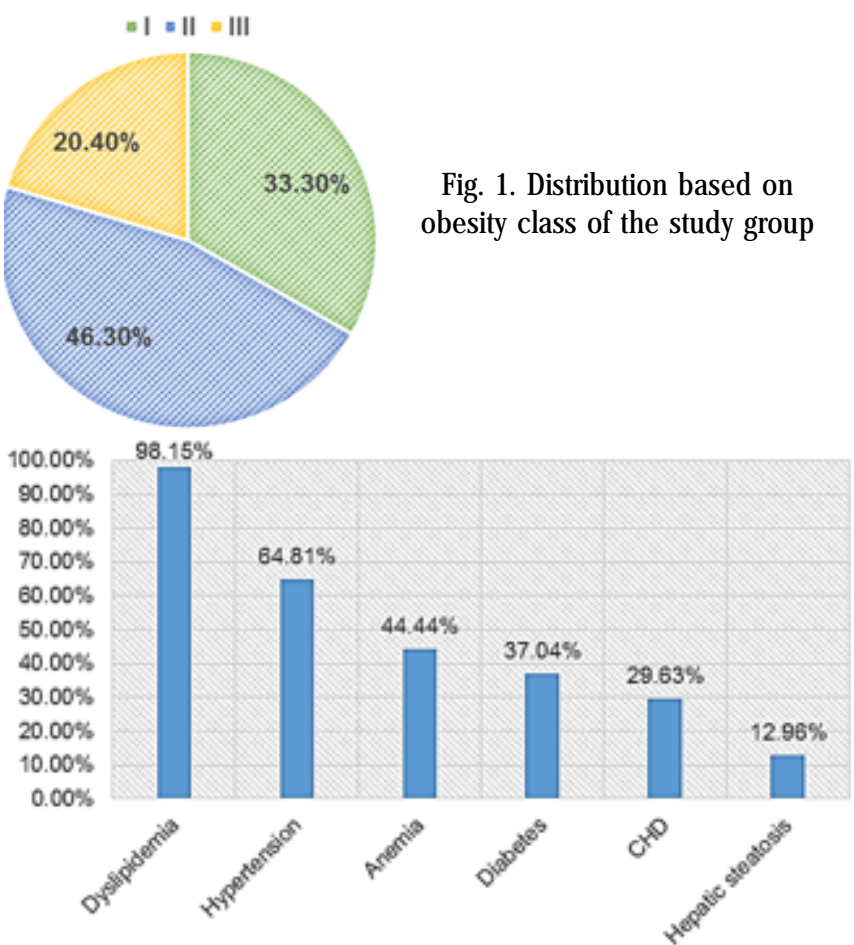

Fig. 2. Comorbidities across the study group.

FORT values were increased in obese patients vs. controls $(3.19 \pm 0.40 \mathrm{mmol} / \mathrm{L}$ vs. $2.16 \pm 0.38 \mathrm{mmol} / \mathrm{L} ; \mathrm{p}$ value $<0.001)$. FORD values were increased in controls vs. obese patients $(1.41 \pm 0.44 \mathrm{mmol} / \mathrm{L}$ vs. $0.66 \pm 0.16 \mathrm{mmol} /$ $L$; $p$-value $<0.001$ ). FORT values were increased and FORD values were decreased in obese patients with comorbidities vs. controls ( $p$-value $<0.001):$ T2DM $(3.33 \pm 0.31 \mathrm{mmol} / \mathrm{L}$ vs. $2.16 \pm 0.38 \mathrm{mmol} / \mathrm{L} ; 0.60 \pm 0.10 \mathrm{mmol} / \mathrm{L}$ vs. $1.41 \pm$ $0.44 \mathrm{mmol} / \mathrm{L}$ ), hypertension ( $3.30 \pm 0.41 \mathrm{mmol} / \mathrm{L}$ vs. 2.16 $\pm 0.38 \mathrm{mmol} / \mathrm{L} ; 0.62 \pm 0.16 \mathrm{mmol} / \mathrm{L}$ vs. $1.41 \pm 0.44 \mathrm{mmol} /$ L), $\mathrm{CHD}(3.29 \pm 0.80 \mathrm{mmol} / \mathrm{L}$ vs. $2.16 \pm 0.38 \mathrm{mmol} / \mathrm{L} ; 0.61$ $\pm 0.14 \mathrm{mmol} / \mathrm{L}$ vs. $1.41 \pm 0.44 \mathrm{mmol} / \mathrm{L})$, anaemia (3.18 \pm $0.33 \mathrm{mmol} / \mathrm{L}$ vs. $2.16 \pm 0.38 \mathrm{mmol} / \mathrm{L} ; 0.66 \pm 0.13 \mathrm{mmol} / \mathrm{L}$ vs. $1.41 \pm 0.44 \mathrm{mmol} / \mathrm{L})$ and hepatic steatosis (3.11 \pm $0.30 \mathrm{mmol} / \mathrm{L}$ vs. $2.16 \pm 0.39 \mathrm{mmol} / \mathrm{L} ; 0.65 \pm 0.12 \mathrm{mmol} / \mathrm{L}$ vs. $1.41 \pm 0.44 \mathrm{mmol} / \mathrm{L}$ ). No significant differences were seen between obese patients with/without comorbidities.

Positive correlations were recorded between: FORT-total cholesterol ( $r=0.31$; fig. 3), FORT-uric acid ( $r=0.25)$, FORDHDL $(r=0.14)$, FORT-LDL $(r=0.24)$, FORT-TG $(r=0.10)$, FORT-HDL/cholesterol ratio $(r=0.24)$, FORD-age $(r=0.08)$ and FORT-BMI ( $r=0.43$; fig. 4). Negative correlations were recorded between: FORD-total cholesterol $(r=-0.27$; fig. 5), FORD-uric acid $(r=-0.30)$, FORT-HDL $(r=-0.09)$, FORDLDL $(r=-0.15)$, FORD-TG $(r=-0.12)$, FORD-HDL/cholesterol ratio $(r=-0.26)$, FORT-age $(r=-0.13)$ and FORD-BMI $(r=-$ 0.35; fig. 6).

Obesity is associated with hyperglycaemia and insulin resistance. Hyperglycaemia and circulating free fatty acids increase ROS production and promote insulin resistance, reduce insulin gene expression and insulin secretion, probably via post-translational repression of some transcriptional factors such as musculo-aponeurotic fibrosarcoma protein A and pancreatic duodenal homeobox-1 which bind to the promoter region of the insulin

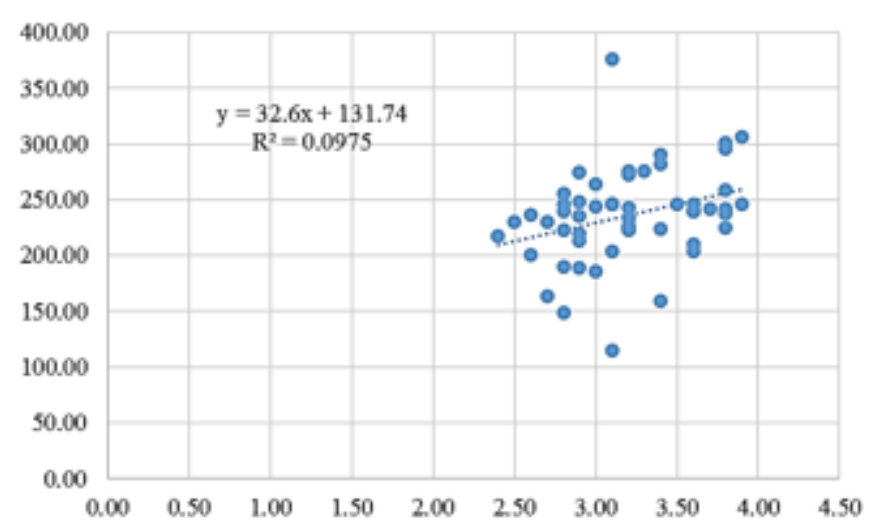

Fig. 3. Positive correlation between total cholesterol and FORT values $(r=0.31)$

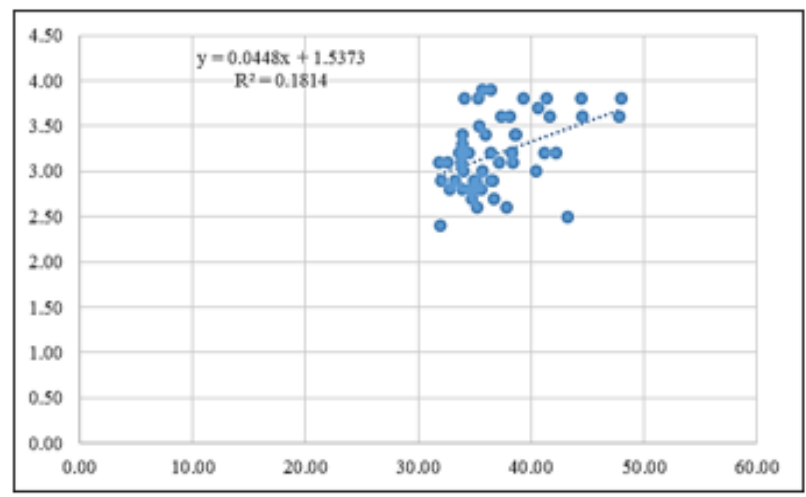

Fig. 4. Positive correlation between BMI and FORT values $(r=0.43)$.

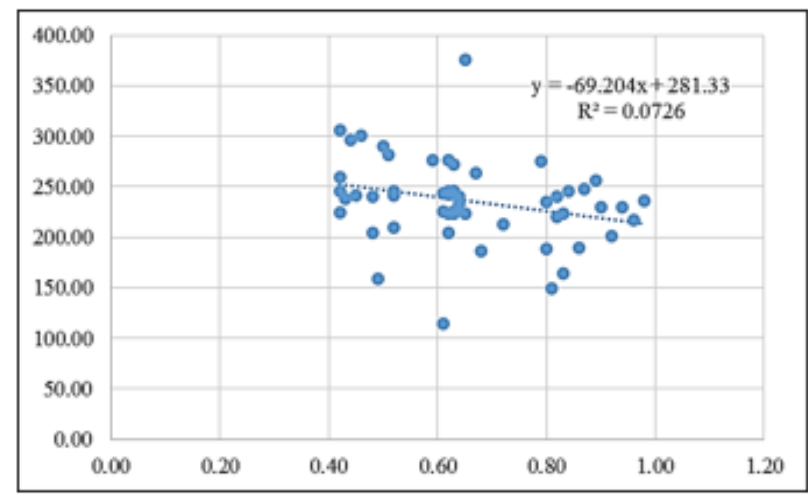

Fig. 5. Negative correlation between total cholesterol and FORD values $(r=-0.27)$.

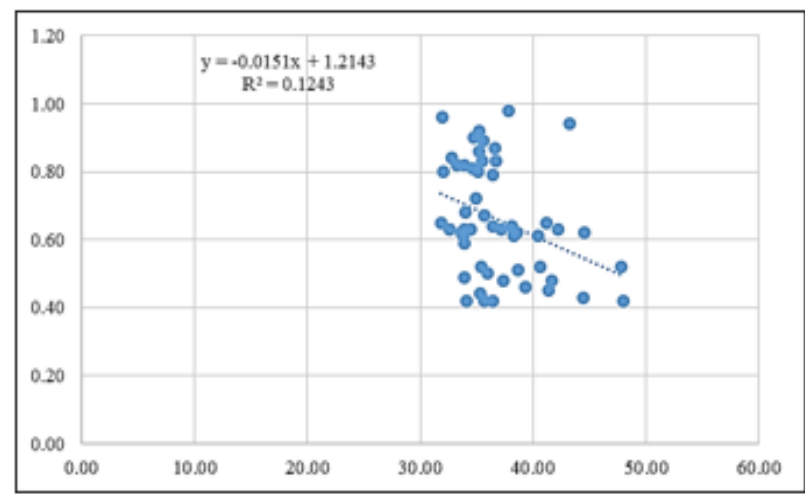

Fig. 6. Negative correlation between BMI and FORD values $(r=-0.35)$

gene [13]. On the other hand, the FoxO family of Forkhead transcription factor regulates gluconeogenesis, adipocyte differentiation, $\beta$-cell proliferation and antioxidantresponse [19]. Advanced glycation end products and the protein 
kinase $C$ pathway stimulate the production of ROS by activating NOX enzymes and NF-kB [20-21]. ROS activate the $\mathrm{c}$-jun- $\mathrm{N}$-terminal kinase, a stress-sensitive serine/ threonine kinase, causing phosphorylation of the insulin receptor substrate at serine residues and thus attenuating insulin signaling [22]. Pancreatic $\beta$-cells have a relatively low expression of many antioxidant enzymes, including catalase and glutathione peroxidase, which makes them susceptible to ROS-induced damage [23].

Low levels of HDL-cholesterol and increased levels of triglycerides and LDL-cholesterol induce ROS overexpression in the endothelium, which causes damage to lipids, proteins or DNA molecules, and modulates intracellular signaling cascades (e.g. MAPK) and redoxsensitive transcription factors, finally promoting the development of atherosclerotic lesions [24].

There is a relationship also between oxidative stress, obesity and cardiovascular disorders. Increased ROS levels in obese subjects lead to changes in lipid expression, induce oxidation of LDL and activation of macrophages, contributing to atherosclerosis. Obesity is also associated with decreased levels of paraoxonase-1, a HDL-attached extracellular esterase that influences the anti-atherogenic, antioxidant and anti-inflammatory properties of HDL [25]. Increased ROS levels induce migration of monocytes/ macrophages and apoptosis of endothelial cells, which promote vascular inflammation and injury, and, in association with oxidized-LDL and adipocyte proliferation, induce progression of vascular disease. LDL oxidation might be related to decreased serum activity of antioxidant enzymes and reduced paraoxonase-1 levels. On the other hand, elevated ROS and $F_{\text {-isoprostanes levels, as well as }}$ a decreased endothelial NO release, induce vasoconstriction and platelet hyperactivity which contribute to the development of arterial hypertension [26]. Platelet oxidative stress is not characteristic to cardiovascular disorders, but is a common finding in essential thrombocythemia as well [27].

Hyperglycaemia and increased fatty acid catabolism in hepatocytes induce excessive electron flux in the mitochondrial electron transport chain, which impairs the oxidative capacity of the mitochondria and stimulates the peroxisomal and microsomal pathways of fat oxidation with an overproduction of ROS. This results in DNA, lipid and protein damage, and increases the risk of hepatic dysfunction, favouring the development of non-alcoholic fatty liver disease (NAFLD) and its progressive form, nonalcoholic steatohepatitis (NASH). NAFLD is characterized by an increase in intrahepatic lipid accumulation due to high inflow of free fatty acid and/or de novo lipogenesis. NAFLD prevalence rises with the increase in BMI [28-30]. High triglyceride concentrations in the liver are associated with an altered metabolism of glucose, fatty acids and lipoproteins, and promote hepatic insulin resistance, T2DM, dyslipidaemia and cardiovascular dysfunction [31-33]. Obesity, NAFLD and T2DM also share a common feature with cognitive impairment and neurodegenerative disorders, i.e. target organ-insulin resistance, in which the contribution of oxidative stress is well established [34-37]. Moreover, the involvement of oxidative stress in the development and progression of solid and haematological cancers has also been extensively studied and explained by various pathogenic mechanisms, including low-grade chronic inflammation, also found in obese patients [3839]. Further studies should be conducted to explore the crosstalk between oxidative stress, obesity, low-grade chronic inflammation and carcinogenesis.

\section{Conclusions}

Our results show that obesity and oxidative stress are linked. Elevated levels of reactive oxygen species and decreased values of antioxidants were registered in obese patients vs. controls, and in obese patients with comorbidities vs. controls. No statistically significant differences were registered in obese patients with comorbidities vs. obese patients without comorbidities. Free oxygen radicals values correlated positively with high lipid values, BMI, uric acid, and negatively with age. Antioxidant levels evolved oppositely.

\section{References}

1.MARSEGLIA, L., MANTI, S., D'ANGELO, G., NICOTERA, A., PARISI, E., DI ROSA, G., GITTO, E., ARRIGO, T., Int. J. Mol. Sci., 16, nr. 1, 2015, p. 378.

2.LE LAY, S., SIMARD, G., MARTINEZ, M. C., ANDRIANTSITOHAINA, R., Oxid. Med. Cell. Longev., 2014, nr. 2014, 2014, p. 908539.

3.MANNA, P., JAIN, S.K., Metab. Syndr. Relat. Disord., 13, nr. 10, 2015, p. 423.

4.FERNANDEZ-SANCHEZ, A., MADRIGAL-SANTILLAN, E., BAUTISTA, M., ESQUIVEL-SOTO, J., MORALES-GONZALEZ, A., ESQUIVELCHIRINO, C., DURANTE-MONTIEL, I., SANCHEZ-RIVERA, G., VALADEZVEGA, C., MORALES-GONZALEZ, J. A., Int. J. Mol. Sci., 12, nr. 5, 2011, p. 3117.

5.SCHIENKIEWITZ, A., SCHULZE, M. B., HOFFMANN, K., KROKE, A., BOEING, H., Am. J. Clin. Nutr., 84, nr. 2, 2006, p. 427.

6.GUH, D. P., ZHANG, W., BANSBACK, N., AMARSI, Z., BIRMINGHAM, C.L., ANIS, A. H., BMC Public Health, 9, nr. 88, 2009, p. 1.

7.WEISS, R., Eur. J. Endocrinol., 157, nr. Suppl 1, 2007, p. S39.

8.*** NATIONAL INSTITUTES OF HEALTH, AND NORTH AMERICAN ASSOCIATION FOR THE STUDY OF OBESITY, NIH Publication Number 00-4084, 2000, http://www.nhlbi.nih.gov/guidelines/obesity/ prctgd_c.pdf.

9.GAMAN, M. A., EPINGEAC, M. E., GAMAN, A. M., Rev. Chim. (Bucharest), 70, no. 3, 2019, p. 977.

10.HOPPS, E., NOTO, D., CAIMI, G., AVERNA, M. R., Nutr. Metab. Cardiovasc. Dis., 20, nr. 1, 2010, p. 72.

11.MANEA, M., MARCU, D., PANTEA STOIAN, A., GAMAN, M. A., GAMAN, A. M., SOCEA, B., NEAGU, T. P., STANESCU, A. M. A., BRATU, O. G., DIACONU, C. C., Rev. Chim. (Bucharest), 69, no. 11, 2018, p. 4180. 12.GURGUL, E., LORTZ, S., TIEDGE, M., JORNS, A., LENZEN, S., Diabetes, 53, nr. 9, 2004, p. 2271.

13.HOU, N., TORII, S., SAITO, N., HOSAKA, M., TAKEUCHI, T., Endocrinology, 149, nr. 4, 2008, p. 1654

14.HARMON, J. S., STEIN, R., ROBERTSON, R. P., J. Biol. Chem., 280, nr. 12, 2005, p. 11107

15.KRAUSS, S., ZHANG, C. Y., SCORRANO, L., DALGAARD, L. T., STPIERRE, J., GREY, S. T., LOWELL, B. B., J. Clin. Invest., 112, nr. 12, 2003, p. 1831.

16.CHANG, L., CHIANG, S. H., SALTIEL, A. R., Mol. Med., 10, nr. 7-12, 2004, p. 65.

17.ZICK, Y., Sci. STKE., 2005, nr. 268, 2005, p. pe4.

18.GAMAN, A. M., BUGA, A. M., GAMAN, M. A., POPA-WAGNER, A., Oxid. Med. Cell. Longev., 2014, nr. 2014, 2014, p. 15835. doi: 10.1155/ 2014/158135.

19.KIM, J. J ., LI, P., HUNTLEY, J., CHANG, J. P., ARDEN, K. C., OLEFSKY, J. M., Diabetes, 58, nr. 6, 2009, p. 1275.

20.DIAZ-MECO, M.T., MOSCAT, J., Immunol. Rev., 246, nr. 1, 2012, p. 154.

21.GAENS, K. H., STEHOUWER, C. D., SCHALKWIJK, C. G., Curr. Opin. Lipidol., 24, nr. 1, 2013, p. 4.

22.HIROSUMI, J., TUNCMAN, G., CHANG, L., GORGUN, C. Z., UYSAL, K. T., MAEDA, K., KARIN, M., HOTAMISLIGIL, G. S., Nature, 420, nr. 6913, 2002, p. 333.

23.ROBERTSON, R.P., HARMON, J.S., FEBS Lett., 581, nr. 19, 2007, p. 3743. 
24.CERIELLO, A., TABOGA, C., TONUTTI, L., QUAGLIARO, L., PICONI, L., BAIS, B., DA ROS, R., MOTZ, E., Circulation, 106, nr. 10, 2002, p. 1211.

25.KRZYSTEK-KORPACKA, M., PATRYN, E., HOTOWY, K., CZAPINSKA, E., MAJDA, J., KUSTRZEBA-W OJCICKA, I., NOCZYNSKA, A., GAMIAN, A., Adv. Clin. Exp. Med., 22, nr. 2, 2013, p. 229.

26.TOUYZ, R. M., Hypertension, 44, nr. 3, 2004, p. 248.

27.MOISA, C., GAMAN, M. A., PASCU, E. G., DRAGUSIN, O. C., ASSANI, D. A., EPINGEAC, M. E., GAMAN, A. M., Arch. Balk. Med. Union, 53, nr. 1,2018, p. 70.

28.ROLO, A. P., TEODORO, J. S., PALMEIRA, C. M., Free. Radic. Biol. Med., 52, nr. 1, 2012, p. 59.

29.FABBRINI, E., SULLIVAN, S., KLEIN, S., Hepatology, 51, nr. 2, 2009, p. 679.

30.LIVADARIU, R. M., DANILA, R., IONESCU, L., CIOBANU, D., TIMOFTE, D., Rev. Chim. (Bucharest), 69, no. 6, 2018, p. 1501.

31.MARCHESINI, G., BUGIANESI, E., FORLANI, G., CERRELLI, F., LENZI, M., MANINI, R., NATALE, S., VANNI, E., VILLANOVA, N., MELCHIONDA, N., RIZZETTO, M., Hepatology, 37, nr. 4, 2003, p. 917.

32.SUMIDA, Y., NIKI, E., NAITO, Y., YOSHIKAWA, T., Free Radic. Res., 47, nr. 11, 2013, p. 869.
33.DE LA MONTE, S. M., Endocrinol. Metab. Clin. North. Am., 43, nr. 1, 2014, p. 245.

34.BADOS-ENRIQUEZ, D. M., LADINO-OYOLA, K. V., YUCUMA-RUIZ, J. E., Int. J. Med. Students, 6, nr. 2, 2018, p. 61.

35.GAMAN, A.M., UZONI, A., POPA-WAGNER., A., ANDREI, A., PETCU, E. B., Aging Dis., 7, nr. 3, 2015, p. 307.

36.MURIACH, M., FLORES-BELLVER, M., ROMERO, F.J ., BARCIA, J.M., Oxid. Med. Cell. Longev., 2014, nr. 2014, 2014, p. 102158.

37.LUIS GOMES, A., DIMITROVA TCHEKALAROVA, J , ATANASOVA, M., DA CONCEICAO MACHADO, K., DE SOUSA RIOS, M. A., PAZ, M. F. C. J ., GAMAN, M. A., GAMAN, A. M., YELE, S., SHILL, M. C., KHAN, I. N., ISLAM, M. A., ALI, E. S., MISHRA, S. K., ISLAM. M. T., MUBARAK, M. S., DA SILVA LOPES, L., DE CARVALHO MELO-CAVALCANTE, A. A., Biomed. Pharmacother., 106, nr. 2018, 2018, p. 1686. doi: 10.1016/ j.biopha.2018.07.121.

38.KARTERJI, M., FILIPPOVA, M., DUERKSEN-HUGHES, P., Oxid. Med. Cell. Longev., 2019, nr. 2019, 2019, p. 1279250.

39.MOISA, C., GAMAN, M. A., DIACONU, C. C., ASSANI, A. D., GAMAN, A. M., Arch. Balk. Med. Union, 53, nr. 4, 2018, p. 529. doi: 10.31688/ ABMU.2018.53.4.07.

$\overline{\text { Manuscript received: } 15.10 .2018}$ 